\title{
Marxismus a česká historiografie: příklad pojmu manufaktura, 1866-1956
}

\author{
ZDENĚK NEBŘENSKÝ*
}

Marxism and Czech Historiography: Example of the Concept manufaktura, 1866-1956

\begin{abstract}
This article deals with the history of the concept manufaktura that came about in the Czech historiography after 1948. Based on an examination of period economic, dictionary and historical writing samples from 17 th-20th century, the article shows which intellectual traditions this term is based upon and which ones it developed. At a general level, it deals with the construction of the terms that historians use and the synonyms that are (not) to be found in the sources. This article attempts to show that the concept of manufactory was not only the result of ideological hegemony in the social sciences and humanities, which was enforced in Eastern Europe after the Second World War. Nor can it be dismissed with references to "ideological ballast" with "extensive factographic heuristics" behind it, as the Marxist historiography is sometimes interpreted. Rather than by adopting the binary view which distinguishes between a "Marxist veneer" and "factography" within the history of historiography, this study shows that a concept of manufactory builds upon a number of texts (and contexts) that came about long before the Communist coup detat.
\end{abstract}

Keywords: Marxist historiography; Bohemian Lands; 17th-20th century; manufactory; factory

DOI: $10.14712 / 23363525.2020 .5$

\section{Úvod}

V prvním dvojčíslí nového časopisu věnovanému hospodářským a sociálním dějinám zveřejnila v roce 1946 členka redakční rady Marie Husová př́íspěvek k historickému pojmosloví. Zabývala se otázkou, zda je nutné při studiu hospodářských dějin 18. století rozlišovat mezi manufakturou a továrnou nebo zda mají oba výrazy stejný význam. Husová píše, že

v písemných pramenech a ve starých tištěných pojednáních o českých průmyslových dějinách užívá se jich smíšeně a nebývají mnohdy přesně rozlišovány ani v novější historické literatuře. Obdobný problém vyskytuje se ovšem i v jiných jazycích a byl pocitován už v 18. století [...] první všestranný rozbor vývoje obou těchto jevů, jak se jevil do poloviny minulého století v západní Evropě, podal Karel Marx v „Kapitálu“. V jeho pojetí představují manufaktura a továrna dvě vývojová stadia kapitalistické výroby. Po Marxovi zabýval se vztahem těchto pojmů zvláště W. Sombart. Ačkoliv je bliže historicky nedefinuje a nevysvětluje, neváhá tvrdit, že Marx se tu dopustil ,jednoho ze svých nejtěžších a nejosudnějších omylư “. Sombart se domnívá, že průmyslová velkovýroba se vyvíjela současně ve formě manufaktur i továren. [Husová 1946: 63]

O téměř deset let později vyšla kniha Manufakturní období v Čechách, ve které její autor Arnošt Klíma pracoval s marxistickým pojetím manufaktury. Podle Klímy existovala v Čechách v 17. a 18. století rozvětvená domácká výroba, která nebyla ničím jiným

* Mgr. Zdeněk Nebřenský, Ph.D., Ústav hospodářských a sociálních dějin, Filozofická fakulta UK, nám. Jana Palacha 2, 11638 Praha 1. E-mail: zdenek.nebrensky@ff.cuni.cz 
než rozptýlenou manufakturou. Doložit lze i koncentrované manufaktury, ve kterých se prosadily kapitalistické vztahy. Problémem bylo, že

prací českých historiků o manufakturách a průmyslovém vývoji Čech 17. a 18. století je málo [...] Mnohdy přejali čeští badatelé hodnocení cizích buržoasních historiků a ekonomů, zvláště Kulischera, Schmollera a Sombarta. Mnohé základní nedostatky, na př́íklad ztotožnění manufaktury s továrnou, se vyskytují jak u českých, tak i u německých historiků. [Klíma 1955: 9]

Klíma prohlašuje, že je důležité rozdíl mezi manufakturou a továrnou objasnit. V návaznosti na zjednodušenou definici Marie Husové tvrdí, že v manufaktuře převládá rukodělná práce, zatímco v továrně se při výrobě používají mechanické stroje [Klíma 1955:10; Husová 1946: 70]. Vedle této definice hledá Klíma pro svoje pojetí také oporu v pramenech, zvláště v historických spisech kameralistů (merkantilistů). Píše, že

všichni merkantilisté, Becher, Schröder a Hörnigk byli rozhodně pro to, aby suroviny byly zpracovány $\mathrm{v}$ zemi a aby výrobky byly $\mathrm{v}$ zemi prodávány [...] první hlasy o nutnosti této cesty se ozývají v českých zemích, na Moravě. Po Morgenthalerovi to byl brněnský zemský advokát F. Š. Malivský z Maliv. [Klíma 1955: 104]

Klíma mimoděk nabízí čtenářům neortodoxní hypotézu, že vedle materiálních předpokladů, podporovaly zakládání manufaktur v rakouských a českých zemích také kameralistické ideje, přesněji řečeno činnost kameralistů, kteří své představy prosazovali v administrativní, vzdělávací a hospodářské praxi [Klíma 1955: 107-116; Wakefield 2009: 2-16].

Je zřejmé, že s pojmem manufaktura jsou spojeny analytické a interpretační obtíže. V písemných pramenech i kameralistických spisech ze 17. a 18. století se objevovaly výrazy manufaktura i továrna („fabrika“) a nebylo jednoduché určit jejich přesný význam. Rakouští, čeští i němečtí „buržoazni“ historici a národohospodáři 19. století označovali raně novověké podniky dobovou terminologií jako „fabriky“, což bylo později pro jejich marxisticky orientované následovníky matoucí.

Terminologický zmatek navíc prohloubil Werner Sombart, který odmítl Marxovu představu o manufaktuře a továrně jako samostatných etapách „kapitalistické výroby“ a tvrdil, že se oba způsoby prolínaly a doplňovaly. Marxističtí historici sice trvali na důsledném rozlišení mezi manufakturou a továrnou, ale pro svoje přesvědčení nenacházeli v pramenech jednoznačnou oporu. O tom, jaký podnik byl nebo nebyl manufakturou, rozhodovali často libovolně, pomocí narativní zkratky či citátem klasiků.

Pojem manufaktura má velmi spletité dějiny. V mnoha didaktických i odborných textech se $\mathrm{s}$ ním čtenáři a čtenářky setkávají dodnes. Je proto důležité podívat se, $\mathrm{z}$ jakých myšlenkových tradic vychází. Historiografie dosud zkoumala především dějiny politických pojmů, at už ve variantě německých Begriffsgeschichte či angloamerických history of concepts [Ira 2004]. Politickými pojmy se ale možnosti tohoto historického přístupu zdaleka nevyčerpávají. Neméně zajímavé výsledky přináší zkoumání pojmů, s kterými pracují historici [Nešpor 1999: 214-227]. Také jejich obsah se během určitého časového úseku proměňoval a často i nadále proměňuje. Historické pojmy navíc odkazují na ekvivalenty, které se nachází (nebo také nenachází) v historických pramenech [Myška 2010: 127-130].

Prostřednictvím pojmů (např. manufaktura) historici tyto prameny strukturují a analyzují. Během této intelektuální operace se však může kvalitativně proměnit vztah těchto pojmů ke skutečnosti: naprŕíklad zavedením pojmu manufaktura bylo v hospodářských 
dějinách novověku vymezeno období, které předcházelo nástupu továrního systému. Marxističtí historici psali o tzv. manufakturním období charakterizovaném akumulací kapitálu, nákladnickým systémem a rozvinutou dělbou práce. Historici techniky zase rozlišovali mezi „proto-továrnou“ a strojovou výrobou [Paulinyi 2002: 219-233]. Nemělo by se proto zapomínat, že s proměnou historických pojmů se proměňuje to, co si historici z „pramenư vybírají, jak prameny interpretují a jak díky nim zobrazují historickou realitu [Horský 2015: 77-79]. Tato proměna však nemusí být definitivní: v závislosti na „pramenech“ se proměňují pojmy a s nimi i historická realita.

$\mathrm{V}$ neposlední řadě nezkoumají dějiny pojmů pojem sám o sobě. V dobovém zvýznamnění může pojem odkazovat k specifickému znaku jisté kulturní konstelace [Řezníková 2018: 35]. I když je možné zkoumat dějiny pojmu manufaktura pouze na základě historických pramenů (učeneckých spisů, archivních dokumentů, vyobrazení atd.) a v tomto ohledu převažuje v práci historiků textová (méně vizuální) komponenta, bylo by samoúčelné omezovat historickou analýzu na rozkrývání tropů a figur, které se v textech a obrazech objevují. Pokud bychom se chtěli odlišit od klasických Begriffsgeschichte či history of concepts, neměly by dnes dějiny pojmů ztrácet ze zřetele své zakotvení v širším sociálně-ekonomickém rámci. Manufaktura nebyla pouze pojmem učeneckých spisů, nýbrž také praktických př́ruček, úřední korespondence, reprezentativních vyobrazení. Je otázka, jakým způsobem zkoumat objektivní historickou realitu, která existovala nezávisle na subjektivitě autorů historických pramenů.

Přestože se v československé historiografii prosadil pojem manufaktura v padesátých letech 20. století, nebyl pouze výsledkem stalinské ideologie [Redlich - Freudenberger 1964]. Jeho používání se nedá odbýt ani poukazem, že byl „ideologickým balastem“, za kterým stála „bohatá faktografická heuristika“, jak se stalinistická historiografie někdy interpretuje [Nodl 2007: 112; Nodl 2007: 153]. ${ }^{1}$ Spíše než prostřednictvím binární představy, která v dějinách historiografie rozlišuje mezi „marxistickým nátěrem“ a „faktografii“, je možné na jeho prríkladu ukázat, že českoslovenští marxističtí historici navazovali na řadu textů (a kontextů), které stalinismu předcházely a vznikaly dlouhá desetiletí před komunistickým coup d’etat.

Stalinismus, včetně historiografie této doby nebyly historickým zlomem či dějinnou diskontinuitou. Byly integrální součástí české a středoevropské vědy a výzkumu. Tato historiografie nezačínala v roce nula resp. 1948, nýbrž vycházela z určitých historických podmínek. Byla důsledkem historického jednání konkrétních osob, které mělo své příčiny. Stalinisté nebyli nepopsaným listem papíru, třebaže mohli na konci čtyřicátých let teprve studovat. Měli nejrůznější, historické (ale samozřejmě i aktuální) motivace, s kterými ke studiu, práci i politice přistupovali [Seidlerová 2004: 16-17; Jiroušek 2004: 24-32; Jiroušek 2008: 14-16; Kábová 2008: 113-144; Rákosník 2008: 292-293; Morávková 2013: 25-32; Górny 2018: 35-43].

Jak naznačují úvodní citace, lze zhruba rozlišit tři základní období, ve kterých se o manufaktuře resp. továrně diskutovalo. První období tvoří spisy a experimenty rakouských (popř. moravských) kameralistů z druhé poloviny 17. a počátku 18. století, ve kterých patřila manufaktura k důležitým tématům. Druhé období zahrnuje zkoumání rakouských

Další problém je, že termín „ideologický balast“ používali stalinisté k denunciaci svých ideových a politických odpůrců. 
resp. česko-německých historiků a národohospodářů z přelomu 19. a 20. století, kteří se drželi pramenné terminologie a rozlišovali mezi manufakturou a „fabrikou“. Třetí období se týká československých meziválečných a poválečných historiků, kteří ve třicátých a čtyřicátých letech 20. století přijali marxistické pojetí, byt to mohlo být v umírněné „sombartovskéc variantě. Manufaktura byla redukována na místo s pokročilou dělbou práce, na kterém se provádí nepř́lišs náročné pracovní operace a využívají jednoduché stroje.

Tato periodizace vyplývá z relevance manufaktury, resp. továrny pro ekonomickou a sociální praxi. Ve druhé polovině 17 . století a na počátku 18. století se v rakouských a českých zemích objevují nové výrobní postupy, které narušují stávající poměry. Cechovní zřízení čelí novým výzvám ze strany dvorských úřadů i šlechtických podnikatelů. V zemi se objevují zahraniční obchodníci a experti nekatolického vyznání. Vybrané skupiny poddaných, kteří jsou zaměstnáni v „komerční výrobě“, dosahují vyšší geografické a pracovní mobility. Některé regiony jsou zapojeny ve větší míře než v minulosti do dálkového obchodu [Ingrao 1994: 91-94].

Výrazné změny jsou charakteristické také pro druhou polovinu 19. století, během které české země prochází zrychlenou industrializací. Je zrušeno poddanství, vytvořen jednotný celní prostor, odstraněna cechovní reglementace, ukončeny tovární monopoly a podpořena volná tržní konkurence. Alfou a omegou hospodářského života se stává průmyslová výroba v továrnách [Good 1984: 13, 129-134; Deak 2015: 132-133].

Ve třicátých letech 20. století dochází k posunu k marxistickému pojetí manufaktury. Jedná se o období velké hospodářské krize, výrazné politické a sociální polarizace a sílící kritiky (industriálního) kapitalismu. Fenomény, které již dříve popsal Marx a kterým se opakovaně dostávalo široké publicity, se obnažují v plné síle. Nadvýroba, inflace, pokles reálné mzdy a masová nezaměstnanost zpochybňují legitimitu hospodářského řádu (včetně tovární výroby) a ospravedlňují státní intervence do ekonomiky. Vítězství sovětského Ruska ve druhé světové válce a vlna zestátnění, které se po roce 1945 přelila Evropou, se zdá být naplněním marxistických předpovědí [Berend 2006].

Studie pokrývá poměrně dlouhé časové období od raného novověku po pozdní industriální modernu. Zatímco výchozí mezník lze určit jen přibližně podle data vydání kameralistických spisů, závěrečný mezník představuje rok 1956. O českojazyčném označení manufaktury (a odtud i o české historiografii) lze v zásadě mluvit až s vydáním první českojazyčné obecné encyklopedie - Riegrova naučného slovníku. V jeho druhém díle, vydaném v roce 1866, se objevila i definice manufaktury, která však byla podrobně vymezena teprve studiemi Jindřicha Šebánka a Bedřicha Mendla ve třicátých letech 20. století. Ve čtyřicátých letech 20. století dochází k proměně obsahu pojmu manufaktura, který zahrnuje politickou instrumentalizaci, ale i další operacionalizaci v historickém výzkumu. S několika menšími exkurzy důležitými pro plynulost argumentace nepřesahuje tato studie rok 1956. Po tomto roce získává manufaktura v české historiografii více méně stálý význam, na kterém se většina české historické obce shoduje [srov. Smutný 2002].

Nabízí se otázka, proč zkoumat pojem manufaktury právě v české historiografii. Na rozdíl od jiných středo- a východoevropských zemí vykazovaly české země od raného novověku pozoruhodnou míru hospodářské a sociální dynamiky, alespoň pokud jde o tzv. proto-industrializaci [Myška 1979; Cerman - Ogilvie 1994] a velmi různorodé prosazování tzv. člověčenství [Cerman 2002: 185-190; Himl 2003: 53-57, 74-79; Štefanová 2009:151, 164; Velková 2009: 406-415; Pražáková-Seligová 2015: 111-147]. Zatímco z východoevropské 
perspektivy patřily české země mezi rychle se rozvíjející region, ze západoevropského pohledu lze mluvit o přetrvávajícím vlivu tzv. druhého nevolnictví a „opožděném“ nástupu laissez-faire. Tento ambivalentní „přechod od feudalismu ke kapitalismu“ byl zajímavý pro československé historiky, kteří se po roce 1948 pokusili ve svém výzkumu uplatnit marxistické kategorie. Nemenší pozornost vyvolal o deset let později také mezi západními historiky [Freudenberger 1958; Hroch 1961; Myška 2013].

Nicméně s překladem Marxovým textů do češtiny se po roce 1953 objevily historické práce, které se snažily ve výzkumu uplatnit původní marxistické pojmy [Klíma 1955; Novotný 1956; Hroch 1956; Válka 1956]. Na rozdíl od východoněmecké historiografie se jich čeští historici nemuseli ortodoxně držet, ale mohli je v dílčích aspektech revidovat [srov. Forberger 1958]. S ještě větší volností mohli s těmito pojmy zacházet díky politické liberalizaci polští, madarští, slovenští či jugoslávští historici. Ti byli i kvưli převážně agrárnímu charakteru raně novověkého hospodářství v jednodušší pozici. Omezená pramenná základna, malý počet „manufakturních“ podniků a prosazení „nevolnictvi“ vymezily marxistickým pojmům zřetelné pole působnosti [Kula 1956; Špiesz 1961; Bićanić 1951].

Západní historici podobná dilemata ve své práci tak intenzivně neřešili: Marxovo pojetí manufaktury odpovídalo podmínkám anglické, francouzské a německé (porýnské) ekonomiky. S pojmem manufaktura zacházeli mnohem variabilněji. Mohli jej využít jako alternativní koncept k hlavnímu proudu dějepisectví, konfrontovat s pramennými doklady, přijmout s výhradou či ho prostě považovat za nepř́liš důležitý [Berg 1994: 61-64; Dobb 1946: 142-149, 259-260; Hobsbawm 1954: 51; Supple 1977: 470-471]. V šedesátých letech 20. století se někteří německo-američtí historici pokusili navrhnout kompromisní pojem „proto-továrna“, který ukazoval na existenci centralizovaných dílen, ve kterých probíhala pokročilá dělba práce a energeticky náročná výroba již na přelomu 17. a 18. století [Redlich - Freudenberger 1964; Mokyr 2003: 247].

\section{Manufaktura v kameralistickém diskursu}

$\mathrm{V}$ následující části se budu zabývat významem, jaký měla manufaktura ve spisech rakouských kameralistů. V posledních letech historici a historičky plédují za to, aby nebyli tito muži označováni jako merkantilisté, nýbrž jako kameralisté. Na podporu svého tvrzení uvádí, že jejich dílo nebylo pouhou středoevropskou variantou merkantilismu, nýbrž představovalo svébytný přístup. Středoevropští kameralisté odpovídali různým definicím a typologiím merkantilismu pouze částečně. Navíc byli velmi heterogenní skupinou. Jejich intelektuální, profesní i životní dráhy se velmi lišily. Spíše než teoretickými ekonomy raného novověku byli úředníky, učiteli a podnikateli. Jejich intelektuální i profesní aktivity byly nesmírně rozmanité. Teprve s odstupem dvou století a sepisováním oborových příruček byl předmět jejich činnosti redukován [Wakefield 2009: 2-16]. Není náhodou, že v českém prostředí se jejich jména vyskytují v přehledech $\mathrm{k}$ dějinám ekonomického i populačního myšlení [Šubrtová 2006: 102-104]. Spíše než o merkantilistech, je proto přesnější hovořit o kameralistech (správcích, úřednících či učencích komory - „Kammer“).

V tomto článku se budu držet označení kameralisté. Jak naznačuje úvodní Klímův citát, marxistická historiografie rozlišuje mezi merkantilisty a kameralisty. Snažit se prohlásit merkantilisty 17. století za kameralisty, přispívá často spíše k zmatení, protože zahraniční badatelé trvají na označení kameralisté. Rozdílné chápání manufaktury mezi kameralisty, 
jakými byli Morgenthaler, Malivský, Becher, Schröder, Hörnigk a jejich následovníky, kterými byli ve druhé polovině 18 . století Justi a Sonnenfels, představuje u zahraničních badatelů zanedbatelnou roli. Významové nuance, např́klad, že se Morgenthaler inspiroval francouzským merkantilismem a Becherovo názvosloví vycházelo částečně z anglických inspirací [Magnusson 2002: 190], neberou př́liš v úvahu. Přesto pro středoevropské kameralisty platí podobně jako pro britské merkantilisty závěr, že zahrnovali neobyčejně širokou oblast vědění: věnovali se otázkám moci, peněz, obchodu, surovin, výroby, blahobytu, práce, lidnatosti, morálky apod. [Stern - Wannerlind 2014: 4-17].

Na rozdíl od metodického př́stupu, který zkoumá politickou a ekonomickou činnost kameralistů, se v této části omezuji na význam pojmu manufaktura v kameralistických spisech. Zatímco kameralistické praxi byla věnována poměrně důkladná pozornost, dějiny kameralistických pojmů byly podřízeny retrospektivnímu př́stupu. Historici a historičky 20. století dávali kameralistickým pojmům moderní obsah. Kameralistická koncepce manufaktury byla považována ekvivalentní té marxistické.

$V$ této části bych chtěl ukázat, že není zcela přesné kameralistickou koncepci manufaktury ztotožňovat s fyzickou budovou - výrobní dílnou („koncentrovanou manufakturou“) či nákladnickým systémem („rozptýlenou manufakturou“). Pro dílnu či faktorství používali kameralisté jiná označení („Werckhaus“, „Verlag“). Kameralistické chápání manufaktury bylo širší. Na tento fakt upozornil ve své diplomové práci v roce 1956 Karel Novotný [Novotný 1956: 6]. Vzhledem k ideologickému významu, s kterým byla manufaktura v této době (ale i v dalších desetiletích) v Československu spojována, nemohl Novotný svůj poznatek zveřejnit. Ve studii, kterou publikoval s jedenáctiletým odstupem, se jeho „revizionistická“ poznámka neobjevila [Novotný 1967]. Novotný se nikdy později nepokusil tento problém systematičcěji ani detailněji sledovat. $V$ práci zveřejněné po roce 1989 respektoval Novotný zavedené (marxistické) pojmosloví [Novotný 1993].

Vzhledem k důrazu, který čeští historici a historičky kladou na Morgenthalerovy, Malivského, Becherovy, Schröderovy a Hörnigkovy politické aktivity [Burian 1961; Maur 1974; Válka 1996; Janák 1999; Šubrtová 2006; Doležalová 2018], omezím svoje zkoumání na tyto osoby. Kameralistické jsou považováni za otce manufakturního podnikání v habsburské monarchii. Kromě vlastního dobového ekonomického kontextu, je pro kameralistické pojetí neméně důležitá návaznost (často nepřiznaná) na předchůdce, opakující se motivy a vzory, přejímání témat. $\mathrm{V}$ tomto ohledu stojí na začátku interpretačního řetězce francouzský obchodník, dvořan a učenec Barthélemy de Laffemas (1545-1612). Klíma např́iklad piše, že „Morgenthaler hájil v podstatě totéž stanovisko, které přednesl ve Francii B. Laffemas" [Klíma 1955: 104].

Laffemas pocházel ze zchudlé šlechtické protestantské rodiny z Dauphiné, odkud odešel do Navarry. Pủvodně pracoval jako krejčí, ale záhy začal obchodovat se stř́brem, stal se dvorním dodavatelem a později také rádcem Jindřicha IV. Ve svém díle se zabýval otázkou, jak zvýšit bohatství francouzské koruny a rozhojnit př́ijmy královské pokladny. Doporučoval rozšírit činnost cechů, zakládat obchodní komory, snížit dovoz zahraničních výrobků a podporovat domácí výrobu. Laffemas zformuloval argumenty, které se v různé podobě a souvislostech opakovaly v dílech středoevropských kameralistů [Klíma 1955: 104; Maur 1974: 139; Šubrtová 2006: 102].

Prvotina dolnorakouského rodáka a brněnského rychtáře Pavla Hynka (Paula Ignaze) Morgenthalera byla kompilací Laffemasových spisů [Morgenthaler 1649: 176-177]. V roce 
1654 se Morgenthaler obrátil na vídeňský dvůr s návrhem, aby byli do země povoláni výrobci zboží, které se muselo dovážet. Podle Morgenthalera odcházelo kvůli dovozu mnoho peněz za hranice. Na francouzských, holandských a anglických prŕíkladech ukazoval, jak zákaz dovozu přivede do země zahraniční odborníky, kteří naučí domácí obyvatelstvo nové druhy výroby. Dokonalejší výrobky („jemnější zboži“ ${ }^{\prime \prime}$ udrží podle Morgenthalera v zemi peníze [Burian 1961: 84; Válka 1996: 174-175].

Na Morgenthalera navázal brněnský zemský advokát Fabián Šebestián Malivský z Maliv, který v roce 1664 poslal do Vídně rozklad dokazující, jak je vývoz nezpracovaného zboží a dovoz kvalitnějších výrobků pro monarchii sociálně a ekonomicky nevýhodný. Malivský tvrdil, že systematická podpora nových druhů výroby umožní zlepšit hospodářskou situaci. Za zmínku rovněž stojí, že Morgenthaler i Malivský zdůrazňovali význam textilní výroby [Klíma 1955: 104-105]. V memorandu, které bylo součástí Malivského rozkladu bylo uvedeno, že zahraniční kupci neměli zájem na tom, aby se určité druhy zboží v dědičných zemích vůbec vyráběly. Chtěli si udržet výhody, které jim z dálkového obchodu plynuly. Naproti tomu autor memoranda plédoval za to, aby se do tohoto obchodu zapojily také další země. Bylo proto žádoucí,

uvést v činnost takové Manufacturn, aby to jeho císařský majestát nestálo nejmenší výdaje, nýbrž o nich nechat zpravit př́slušné země, což v nich povede jeho nejjasnější milosti $\mathrm{k}$ jejich lepšímu přijetí [...] aby neodcházelo do cizích zemí tolik peněz za zahraniční zboží, je třeba zavést všechny druhy cizích Manufacturen a obdařit každou zemi jeho nejjasnější milosti privilegii. ${ }^{2}$

Z citované ukázky (a dalších úryvků v memorandu) není zřejmé, jak manufaktury vypadaly. Memorandum popisuje manufaktury velmi obecně a metaforicky. Jsou zdrojem bohatství. Dokáží v zemi udržet peníze. Mohou v jednotlivých dědičných zemích přeměnit místní suroviny ve zboží, které se musí draze dovážet ze zahraničí. V memorandu nemají manufaktury jednotné číslo. Vystupují v plurálu. Na některých místech autor rozlišuje mezi Manufacturn a Manufacturen. Memorandum neříká nic o jejich založení nebo stavbě. Dozvídáme se, že manufaktury lze v zemi zavést popřípadě do země uvést. Nepřímo souvisí s prací a obchodem. Důležitou podmínkou bylo, aby zavedení cizích manufaktur (výrobních odvětví) bylo podpořeno císařskými privilegii. Ve vybraných městech a panstvích měli být do manufaktur přivedeni zahraniční řemeslníci, které měla mít na starosti císařská komise [srov. Klíma 1955: 105-106].

Nedostatek adekvátních pramenů a podrobnějších zkoumání neumožňuje odpovědět na otázku, co vedlo právě brněnské měštany $k$ tomu, že se na základě svých vlastních zkušeností s manufakturním podnikáním pokusili zformulovat doporučení obecnější povahy. Důležitou okolností bylo, že vídeňské úřady po opakovaných urgencích Malivskému jménem císaře Leopolda I. odpověděly a vyzvaly moravský Tribunál, aby se problematikou výroby („,comercien“) zabýval. Navíc Vídeň nechala prošetřit výrobní záležitosti také v ostatních korunních zemích. Malivský vycházel ze svých praktických zkušeností: v Brně na Radlase, v Ivančicích a Tišnově provozoval podloudně textilní podniky. Ty však po jeho smrti zanikly [Klíma 1955: 106; Válka 1996: 174-175].

V době, kdy se dvorští hodnostáři zabývali Malivského memorandem, bylo ve Vídni v roce 1665 založeno komerční kolegium (Commerzkollegium). Kolegium se mělo

2 Moravský zemský archiv (MZA), Fascikl Fabián Šebestián Malivský z Maliv, ka. 1253, sign. M106, f. 97. 
zabývat obchodem, řemeslem a výrobou. Řemeslná a zemědělská výroba vyčerpala své možnosti a dvorské kruhy hledaly další prostředky, ze kterých by bylo možné financovat vojenské a velmocenské výzvy [Schindler 1904: 7-8, 13-19; Klíma 1955: 86-89, 107]. Předním členem kolegia byl Johann Joachim Becher, který se ve svém díle Politischer Discurs manufakturám zevrubně věnuje. V prvním vydání z roku 1668 Becher tvrdí, že přišel do Vídně:

abych nikoliv ke škodě, nýbrž k užitku jsem přispěl; zvláště tak, aby to bylo možné, všemi druhy manufacturen, ze kterých nyní mnoho peněz do ciziny odchází, v císařských dědičných zemích se zabýval [...] Poté byla moje maličkost jmenována do kolegia a v rámci něj mi byla dána komise, aby zavedla několik manufacturen, kterým jeho císařský majestát také milostivě privilegia udělil, což bylo mezi kupci známo; nelze věřit ani popsat, kolik uvedených manufacturen obchodníkům neškodilo, ani nepřekáželo. [Becher 1668: Dedicatio nestránkováno]

Citát naznačuje, že již před příchodem Bechera v dědičných zemích existovaly manufacturen, ze kterých plynuly do zahraničí finanční prostředky. Becherovým úkolem bylo zavést, popř. uvést do země několik manufacturen, aby tomuto odlivu peněz do ciziny zabránil. Pokud chápeme manufaktury výhradně jako dílny, nedává Becherova výpověd přiliš smysl. Když ale připustíme, že termínem manufacturen mohl Becher myslet různé druhy výroby, popř. výrobní odvětví, které produkovaly nové výrobky, dostane Becherovo prohlášení další význam. Becherovy manufacturen odkazují k latinské etymologii, resp. k dobovému anglickému úzu, ze kterého termín přejal [Teich 2015: 116].

Z Becherova používání termínu manufacturen (nebo na dalších stranách knihy také Manufacturn) není zřejmé, že jsou jím myšleny velké dílny s mnoha desítkami pracovníků soustředěných pod jednou střechou, jak je manufaktura obvykle v historiografii prezentována. Becher nemluví ani o rozptýlených dílnách, ve kterých se dokončují nehotové výrobky. Pokud explicitně odkazuje na místo, ve kterém se pracuje, používá termín Zuchthaus a Werkhaus. V souvislosti s odchytem „žebráků, chudáků a sirotků", mluví o káznicích a werkhauzech, ve kterých mají být „potulující se čeledi přistřižena křídla“. Becherovo zacházení s termínem manufacturen/Manufacturn je variabilní [Becher 1668: 5, 132-134, 197-198, 233-237; Becher 1673: 289-292].

Na Becherovo dílo navázal jeho švagr a spolupracovník Phillip von Hörnigk, který ve svém spise Österreich über alles, wann es nur will formuloval devět normativních hospodářských zásad pro pozvednutí impéria. Vedle všestranné podpory domácí výroby a zákazu dovážet zahraniční výrobky, věnoval Hörnigk jeden bod také otázkám lidnatosti a pracovitosti. Pokud jde o manufaktury, tak v Hörnigkově spise vystupují jako určitý princip či zpo̊sob výroby, který umožňuje zpracování surovin a produkci zboží, jehož prodej přináší do země peníze. Naopak zboží zahraniční výroby („auswärtige Manufacturen“) zemi poškozovalo. Hörnigk navrhoval, aby byla zakázána

[zahraniční] vlněná manufaktura jako je sukno, látka nebo pletená práce; s výjimkou pytloviny do komory na chleba, jejíž výroba se na pár let v dědičných zemích pozvedla. Za druhé všechno lněné zboží ze zahraničí pokud je to možné; za třetí hedvábná manufaktura ve všech jejích stupních. Za čtvrté všechno co je vedeno pod značkou francouzských manufaktur [...] Jisté je, že tyto čtyři manufaktury jsou jako čtyři nehospodárné šelmy, které samotné nám každoročně odnášejí z měšce šestnáct a více miliónů zlatých. [Hörnigk 1684: 144-146] 
V souvislosti s výrobou módního zboží, které se do střední Evropy šíriilo především z Francie, používá Hörnigk termín fabrica. Podobně jako manufaktura, také fabrika není přesně určeným místem, ale spíše způsobem výroby. Ještě jiný význam mají Fabriquen, které je možné s jistou mírou zjednodušení považovat za výrobní jednotky. Kromě toho popisuje Hörnigk také zařízení, která měla nepřehlédnutelné prostorové dispozice, nebyla však manufakturami ani fabrikami. Hörnigk doporučuje výstavbu hal a skladů, ve kterých mělo být uloženo plátno a sukno, aby mohly úřady kontrolovat jeho kvalitu. Hörnigk tvrdí, že toto opatření přispěje k vyššímu prodeji domácích výrobků, protože kupci budou mít jistotu, že nebudou podvedeni [Hörnigk 1684: 182, 234].

Mezi další hojně citované autory patří Wilhelm von Schröder, jehož práce Fürstliche Schatz- und Rentkammer se zařadila mezi oblíbené učebnice politické ekonomie a byla opakovaně vydávána až do začátku 19. století. Podle Schrödera tvoří manufaktury základ bohatství každé země. Schröder používá termín manufaktura převážně ve smyslu výrobního odvětví nebo skupiny řemesel. V kapitole týkající se zavedení „manufakturního inventáře“ a „celního registru“ Schröder uvádí, že nejprve je nutné zjistit

která manufaktura by byla zemi více ku prospěchu. Aby bylo možné se toto dozvědět, musí se nejdříve vidět, zda se manufaktura v zemi uživí; předem je nutné takovou manufakturu se naučit $[\ldots]$ potom musíme také zvážit, co a jak tato manufaktura splétá, nebot čím více peněz jedna manufaktura z jedné země do jiné přinese, tím užitečnější té zemi je. [Schröder 1752: 73-75]

Schröder doporučuje panovníkovi, aby zř́idil manufakturní úřad („Manufakturamt“), který bude pečlivě evidovat řemeslníky, obchodníky a výrobce. Pojetí manufaktury jako dílny či skupiny dílen, umístěných v jednom objektu se blíží manufakturní dům („Manufakturhaus“), který ovšem Schröder zároveň chápe jako vzdělávací a výchovné zařízení. $\mathrm{V}$ neposlední řadě představuje manufaktura, popř. manufakturní dům prostředek pro nápravu lidí na okraji - tuláků, žebráků, sirotků a povalečů. Podobně jako Becherův a Hörnigkův spis, také Schröderova prŕručka tak spojuje ekonomiku a výrobu s morálkou [Schröder 1752: 80].

S válkami o rakouské dědictví se začala psát nová kapitola středoevropského kameralismu. Vedle starší tradice, o které byla řeč na předchozích stranách, recipovali kameralisté myšlenky francouzských fyziokratů, kteří plédovali za liberalizaci vnitřního obchodu a rozvoj zemědělství. Dvorské kruhy se opakovaně zabývaly problémem, jak lépe využít potenciál spočívající v početném poddanském obyvatelstvu. Ưředníci konstatovali, že lidé v dědičných zemích jsou chudí a nemají dostatečnou ekonomickou ani kupní sílu, aby mohli podporovat trh s průmyslovým zbožím. Velkým tématem se stal všeobecný „blahobyt", dodržování právního řádu, ochrana soukromého vlastnictví a poměr mezi jednotlivcem a společností [Freudenberger 2003: 87-89].

\section{Pojem „fabrika“ a „továrna“ v česko-německé historiografii poslední třetiny 19 . a první třetiny 20 . století}

Jak zaznělo v úvodním citátu, vyčítá Klíma českým badatelům, že přejali hodnocení „cizích“ historiků a ekonomů. Konkrétně jmenuje Hermanna Hallwicha, Josefa Helferta, Antona A. Paudlera, kteří podle něj chybně ztotožňovali manufakturu s továrnou. $\mathrm{Na}$ několik dalších rakouských „buržoazních“ předchůdců Klíma odkazuje ve své knize. 
Reviduje závěry či polemizuje s výsledky bádání Christiana d’Elverta, Augusta Fourniera, Alfreda F. Pribrama a Karla Přibrama, abych uvedl ty nejcitovanější. Dříve než bude možné zjistit, v čem spočívalo „chybné“ ztotožnění manufaktury a továrny, bude vhodné připomenout, prostřednictvím jakých pojmů zkoumali tito pánové hospodářské dějiny raného novověku.

Zjednodušeně lze říci, že česko-němečtí historici, politici a národohospodáři neoznačovali raně-novověké podniky jako manufaktury, nýbrž jako fabriky. Přívlastek manufakturní měly úřady a úředníci, kteří se agendou fabrik zabývali. Moravský liberální politik a historik Christian d'Elvert ve svých „kulturních dějinách“ Moravy a Rakouského Slezska popisuje, jak vláda v šedesátých letech 18 . století zřídila v Brně s velkými náklady fabriku na jemná sukna na předměstí Velká Nová (dnešní Lidická ulice). Významným podnikem byla podle d'Elverta také „fabrika“ na plyš, pro kterou císařovna koupila a nechala rozšířit dům na Švábce [d'Elvert 1870: 71]. Profesor obecných a rakouských dějin na Německé univerzitě v Praze August Fournier označuje ve svých dějinách rakouské komerční politiky hornolitvínovskou manufakturu jako fabriku a největší rakouské podniky v Linci a Schwechatu nazývá „fabrikami“ [Fournier 1886: 342-352]. Profesor novověkých dějin na Vídeňské univerzitě Alfred F. Pribram charakterizuje první podniky v Linci a Vídni jako fabriky [Pribram 1898: 10; srov. Luschin von Ebengreuth 1896: 488-489]. Docent politické ekonomie a pozdější profesor hospodářských věd Karl Přibram píše, že nejstarším průmyslovým podnikem v Rakousku byla linecká fabrika na vlněné zboží, založená v roce 1672 . V Čechách patřila podle Přibrama k předním podnikům Valdštejnova fabrika na sukna v Horním Litvínově [Přribram 1907: 15-16].

Toto „chybné“ názvosloví přejal i český národohospodář Emanuel Schindler, podle kterého byl podnik, založený v Linci místním měštanem Kristiánem Sindlem, fabrikou na výrobu jemného sukna anglického a holandského druhu [Schindler 1904: 25]. S odkazem na Codex Austriacus Schindler konstatuje, že tento „ein dem Publico nützliches Werck“, titulovaný jako „keyserliche Fabrica und Manufacturs-Handlung“ či „Land-Fabrica“ obdržel řadu dvorských výsad [Codicis Austriaci: 271-274]. Významový posun zaznamenaly historické pojmy u Josefa Pekaře, který v předválečném i poválečném vydání své středoškolské učebnice označuje raně-novověké podniky továrnami: včetně „továrny“ založené v roce 1715 v Horním Litvínově [Pekař 1914: 112; Pekař 1921: 101].

Důležitým kritériem pro označení raně novověkých podniků fabrikami byla terminologie pramenů. Např́iklad Loscaniho relace o komerciálních poměrech v Čechách v polovině 18 . století, která byla publikována v roce $1887 \mathrm{v}$ archivu pro rakouské dějiny, se v nadpise zmiňuje o povznesení různých druhů manufaktur („Relation über alle in folgenden fünf Commercialkreisen erhobenen Manufacturs-Gattungen“). Ve vlastním textu se však objevují funkční označení jednotlivých podniků, např. bělidlo, valcha, barvírna, hut', hamr apod. V popisu litoměřického kraje jsou potom doslovně uvedeny fabriky na vlněné látky a sukna („Wollen-Zeug-Fabrique“, resp. „Tuch-Fabrique“). Dále je zmíněna fabrika na výrobu flanelu v Herálci u Humpolce („Flanell-Fabrique“) [Loscani 1756: 475, 481].

Také Pribramem vydaná zpráva Stefana Josefa Handera z roku 1729 o stavu slezských, moravských a českých soukenických fabrik a manufaktur („Bericht über Status schlesischer, mährischer und böhmischre Tuchfabriken und Tuchmanufacturen“) má v názvu oba výrazy. Jakmile však začne Hander popisovat podniky na jednotlivých místech, která navštívil, termín manufaktura již nepoužívá. Podle všeho se zdá, že manufakturou mínil 
Hander textilní výrobu mnoha desítek jednotlivých soukeníků, od kterých odebírali zboží faktoři a nákladníci. V tomto ohledu se Hander v Novém Jičíně, Fulneku nebo Liberci s žádnou fabrikou nesetkal. Snad by mohl být tento způsob kooperace synonymem pro označení rozptýlené manufaktury. Naproti tomu Broumov, Česká Lípa nebo Horní Litvínov se pyšnily soukenickými fabrikami, barvírnami a výrobnami. Sukno bylo vyráběno ve fabrických domech [Pribram 1898: 231-237].

Rozdíl mezi odborným historickým a národohospodářským označením továrny, resp. manufaktury na jedné straně a používáním těchto termínů v ekonomické praxi dokládá vyjádření obchodní a živnostenské komory z června 1912. Představitelé komory uvedli, že

mezi českým „výroba zrcadel“ a německým „Spiegelmanufaktur“ neshledává komora divergence, protože pro podstatné jméno „Manufaktur“ speciálního českého názvu nemáme a obvykle užívá se tu v češtině všeobecnějšího výrazu „výroba“. 3

I když se samozřejmě mohlo jednat o ojedinělý př́ípad, jehož zvláštnost podtrhoval překlad z německého do českého jazyka, není bez zajímavosti, že chápání manufaktury jako výroby v nejširším slova smyslu nebylo nepodobné habsburským kameralistům z přelomu 17. a 18. století. Nelze samozřejmě předpokládat, že stranou učených rozprav, mezi (českými) hospodářskými praktiky, přežíval bez významových změn více než dvě století ojedinělý termín. Nicméně lze dobře doložit, že přinejmenším mezi představiteli pražské živnostenské komory, neměla v roce 1912 manufaktura marxistický význam budovy či pevně ohraničeného místa, na kterém se pod jednou střechou shromaždují zaměstnanci pracující za mzdu.

Někteří česko-němečtí historici pomíjeli pojem manufaktura ještě v meziválečném období. Vycházeli z edice pramenů, která podrobně zachytila komunikaci kolem provozu hornolitvínovského podniku. V těchto pramenech nebyla po manufaktuře ani stopy. Čtenáři se tak mohli např́íklad dozvědět, že J. J. Valdštejn požádal v květnu 1715 císařský dvưr o povýšení vsi Horní Litvínov na městys, aby podpořil vznikající fabriku na sukna („zur Förderung der errichtenden Tuchfabrik“). V roce 1718 si v jednom z dopisů stěžuje vídeňský agent, jak je obtížné zajistit vzorek španělské vlny pro „fabriku na sukna jeho nejlaskavější excelence“ („Euer hochgräslichen Exzellenz Tuchfabrik“). O několik měsíců později referuje tentýž agent o tom, jak se zamýšlený manufakturní ředitel „poptával na fabriku jeho nejlaskavější excelence“ („wegen Euer hochgräslichen Exzellenz Fabrik zu unterreden verlange“). V konceptu dopisu z února 1723 děkuje J. J. Valdštejn krajskému hejtmanovi za jeho úsilí při hledání zběhlých soukeníků a vyslovuje přání, aby tito lidé „svoje řemeslo ve fabrice vykonávali s lepším vědomím“ („eine bessere Wissenschaft in ihrem Handwerk in der Fabrik beigelegt“). V srpnu 1727 informuje J. J. Valdštejn komerčního radu, že „jeho fabriku ovšem postihne ten tak dobře míněný projekt“ („übrigens auf das meiner Fabrik so gut gemeinte Projekt zu kommen“), který měl zakázat zahraniční obchod se suknem. Valdštejn varoval předtím, že pokud „by měli Židé vykoupit všechno sukno z mé fabriky“ („nun aber die Juden alle Tücher überhaupt von meiner Fabrik erkaufen sollten“), soukeníci mohou lehce ztratit svoji obživu [Richter 1933: 232-243].

3 Státní oblastí archiv (SOA) Praha, fond Krajský soud obchodní Praha, ka. 2066, sign. C III - 115. Za upozornění a nalezení dokumentu děkuji Svatoplukovi Hercovi. 


\section{Manufaktura v československé meziválečné a poválečné historiografii}

V době, kdy Johann Richter vydal v Mittheilungen des Vereines für Geschichte der Deutschen in Böhmen sbírku citovaných dokumentů k dějinám hornolitvínovské „fabriky“, začali jeho čeští kolegové testovat analytické možnosti pojmu manufaktura. Nejpodrobnější výzkumy $\mathrm{z}$ hospodářských dějin raného novověku publikoval na počátku třicátých let 20. století Jindřich Šebánek, který se zabýval textilními podniky moravských Kouniců. Šebánek s termínem manufaktura pracoval, i když ho dával uvozovek. Jeho nejistotu, popř. pochybnosti ohledně validity prozrazují závorky, ve kterých Šebánek uváděl dobové výrazy z úředních pramenů („manufakturní dům“, „dílo“, „podnik“) [Šebánek 1931; Šebánek 1932]. Z Šebánkova zacházení s manufakturou však nebylo zřejmé, zda ji přikládal stejný význam jako Marx.

Odpověd’ na tuto otázku poskytují autority, na které se Šebánek odvolává. Ve své úvodní poznámce k pojmosloví Šebánek odkazuje na Bedřicha Mendla a Karla Büchera. Bücherova učebnice národní ekonomie, kterou do češtiny přeložil Josef Gruber, manufakturu jako výrobní jednotku neregistruje. Bücher rozlišuje mezi cechovní, řemeslnou, domáckou a tovární výrobou [Bücher 1897: 76-98]. Naproti tomu u Mendla představují manufaktury spolu s domáckou výrobou jeden z předpokladů továrního průmyslu [Mendl 1931: 126-129]. Podle Mendla se manufaktury způsobem výroby nelišily od dílen cechovních řemeslníků. Vynikaly však rozsahem. Jednomu podnikateli nebo podnikatelské společnosti bylo podřízeno množství pracovníků. Velké podniky byly tzv. továrními privilegii vyjmuty z cechovní organizace a získaly větší ekonomickou svobodu [Mendl 1939: 493].

Nicméně Mendl nevychází ve svém výkladu z Marxe, nýbrž z Wernera Sombarta a Josefa Kulischera. Sombart byl sice v mládí „přesvědčeným marxistou“, později ale tvrdil, že pokud jde o manufakturu, tak se Marx dopustil „jednoho ze svých nejtěžších a nejosudnějších omylü“ [Kan 1952: 27]. Na rozdíl od Marxe nepovažuje Sombart manufaktury za „přechodnou formu“ mezi agrárně-řemeslným a průmyslově-kapitalistickým hospodářstvím. Sombart nespatřuje v manufaktuře něco historicky kvalitativně nového, co by odlišovalo individuální podnik (řemeslnou dílnu) od společenského charakteru výroby (zespolečenštění výroby v továrně). Manufaktury netvoří podle Sombarta samostatný vývojový stupeň kapitalistické výroby. Podle Sombarta koexistují v téže době manufaktury i továrny [Sombart 1902: 38-43]. Mendlovy práce z třicátých let, které do české historiografie uvedly prostřednictvím Sombarta termín manufaktura, ovlivnily díky kontaktům svého autora i další historiky.

Instruktivní se ukázal být také pohled do dobových naučných slovníků, ve kterých se během sedmi desetiletí mění manufaktura $\mathrm{z}$ dílny $\mathrm{v}$ předchůdkyni továrny. $\mathrm{V}$ pátém díle Riegrova slovníku z roku 1866 je u manufaktury uvedeno jediné slovo („rukodílna“) a odkaz viz fabrika [Slovník naučný 1866: 99]. Autor hesla v Ottově slovníku naučném uvádí v roce 1900, že manufaktura je „živnost prováděná rukama, popř. se jedná o rukodělné zboží či výrobky textilního průmyslu“ [Ottův slovník naučný 1900: 791]. V Masarykově slovníku z roku 1929 je manufaktura označena jako „rukodílna resp. velká řemeslnická dílna, ve které probíhá výroba ručními nástroji“. Manufaktura je předchůdkyní továrny, která ji po zavedení strojové výroby vytlačila [Masaryk 1929: 725]. Podobný význam má manufaktura v encyklopedickém německo-českém slovníku: německý výraz Manufaktur 
je přeložen jako „manufaktura“ a „rukodílna“, může být také synonymem fabriky [Sterzinger 1931: 63]. Jestliže slovníky zachycují nejobecnější významy rozšířené v dané době v společenské komunikaci, pak k rozlišení mezi manufakturou a továrnou došlo v českém jazyce na přelomu dvacátých a třicátých let 20 . století.

Ve změněné politické a intelektuální atmosféře navázala (velmi kriticky) na meziválečné koncepce po roce 1945 Marie Husová. Ve své stati se explicitně přihlásila k marxistické definici manufaktury. Husová dala tomuto stále poměrně neurčitému konceptu kategorickou definici. Spolu s Marxem Husová tvrdí, že manufaktura a továrna představují dvě odlišná vývojová stadia kapitalistické výroby. Autoři (např. Sombart, Kulischer, Gruber), kteří zpochybňují, že raně novověké manufakturní dílny měly kapitalistický charakter, zacházejí podle Husové s pojmy nereflektovaně a libovolně je zaměňují.

Husové nejde o pojmenování jako takové, nýbrž o tzv. obsah pojmu, který se historicky proměňuje. Přestože si je Husová vědoma, že prameny označují raně novověké podniky jako fabriky (fabric, fabriqe, Fabrik), tvrdí, že jsou to manufaktury kvalitativně odlišné od továren. S tímto poznatkem by jmenovaní autoři nepochybně neměli problém: nikdo z nich netvrdí, že se raně novověká a moderní továrna neliší. Stejně tak by souhlasili, že obsah pojmu není statický, jak jim Husová podsouvá. Jediný rozdíl spočívá v jejich kritickém přístupu k Marxově interpretaci manufaktury jako samostatné vývojové etapy kapitalistické výroby, na kterém Husová trvá [Husová 1946].

Její zatvrzelost nebyla pouze výsledkem ideologické ortodoxie, nýbrž také tím, co bychom mohli nazvat „jazykovým determinismem“. Český jazyk totiž nemá pro označení raněnovověkých podniků adekvátní pojmenování. Termín fabrika pochází z němčiny a jako takový začal být ve druhé polovině 19. století vnímán jako nečeský a nespisovný. Český obrozenecký neologismus „továrna“, odvozený od „tovaru“ (zboží), byl utvořen ve dvacátých letech 19. století, tedy v době, kdy se prosazovala průmyslová výroba kvalitativně odlišná od raněnovověkých dílen. Na rozdíl od většiny evropských jazyků, v nichž měla fabrika jistou kontinuitu, neexistoval v češtině pro raně novověké podniky výraz, který by byl srozumitelný a logický.

Podobný problém se objevuje v citované práci Arnošta Klímy Manufakturní období $v$ Čechách, ve které jsou raně novověké podniky nazývané manufakturami, přestože v pramenech se objevuje výraz fabrika. Klíma např́klad odkazuje v poznámce pod čarou na zprávu komerčního kolegia, v níž je uvedeno, že v říjnu 1723 se Johanna Gallasová a její hejtman Eliáš Kessler obrátili na císařský dvůr, aby mohli v Hrádku nad Nisou postavit podnik, který by zaměstnával a vyučoval toulavé a žebravé chlapce a dívky („vagierenden Bettelleuthe Knaben und Mägdel aufzuheben, und in die Fabrique was zu erlernen applicieren könne“). Zpráva oceňovala, že podnik byl situován na místě, na kterém byla velká bída a lidem tak mohl obstarat obživu („diese Fabrique an einem solchen Orthe situirt ist, wo wohin nicht das geringste gewesen und also mittels solcher denen im Gebirge wohnenden und durch Spinnen, Woll lessen und anderen zur Fabrique gehörenden sachen der Unterhalt kann verschafft werden“) [Klíma 1955: 243].

Marxistického termínu manufaktura se důsledně držel i František Mainuš, který ve stejné větě současně uváděl označení z pramenů. Mainuš například píše, že v roce 1768 dostala správa pernštýnského podniku povolení zřídit pro své zaměstnance tzv. tovární cech („Weber-Fabrique-Zunft“), který ve stejné době existoval již v harrachovském podniku v Janovicích u Rýmařova. O dva roky později požádal J. J. Stockhammer dolnorakouský 
komerční konses o povolení, aby podnik směl užívat označení k.k. privilegierte Perstejner Leinwandtfabrique a prodávat tři roky lněné výrobky ve velkém. Podobnou diskrepanci mezi heuristickými nástroji a dobovou terminologií lze najít i na dalších stranách [Mainuš 1959: 132, 219].

Dalším problémem bylo, že českoslovenští historici prezentovali výsledky své práce $\mathrm{v}$ řadě cizojazyčných studií, které byly publikovány $\mathrm{v}$ předních anglickojazyčných časopisech [Klíma 1959; Klíma 1965; Klíma 1974; Klíma 1975; Klíma 1977; Myška 1979]. Tyto studie představovaly pro zahraniční publikum dlouhou dobu jediné příspěvky $\mathrm{k}$ hospodářským dějinám českých zemí raného novověku. Někteří angličtí a američtí historici marxistické pojetí, včetně pojmu manufaktura („manufactory“) akceptovali. Nepřímo tak zdůraznili specifikum českých hospodářských dějin raného novověku. Jiní pojem nepřijali a ve shodě s anglickou historickou terminologií označovali raně novověké podniky i nadále jako továrny („factories“) [Freudenberger 1960: 389].

\section{„Kapitalistický charakter“ manufaktury?}

Vedle mnohoznačnosti představoval problém také postupný vývoj samotného pojmu manufaktura u Marxe. Jednu z prvních reflexí najdeme ve francouzsky psaném spisu Bída filozofie z roku 1847. V něm Marx tvrdí, že předpokladem pro vytvoření manufakturního průmyslu byla akumulace kapitálu související se zámořskými objevy a dálkovým obchodem. Dále to byla volná pracovní síla, která se rekrutovala z řad tuláků a rolníků zbavených půdy, kteří disponovali pouze silou svých rukou. V neposlední řadě se jednalo o koncentraci pracovní síly na jednom místě („v jedné místnosti“), ve které docházelo k dělbě práce a provádění jednoduchých specializovaných úkonů [Marx 1950: 119].

Tyto předpoklady zopakoval Marx společně s Engelsem o rok později v Manifestu komunistické strany. $\mathrm{V}$ něm představili třístupňový model průmyslové výroby. Na jeho počátek postavili řemeslné a cechovní dílny, které vystřídal nákladnický systém a manufaktura a ty pak tovární průmysl. Podle obou klasiků položila manufaktura základy pro kapitalistickou výrobu. Feudální a cechovní způsob výroby nestačil v důsledku zámořských objevů a rozvoje dálkového obchodu reagovat na zvyšující se poptávku a expandující trhy. Cechovní mistři byli vytlačeni manufakturními podnikateli, kteří nahradili dělbu práce mezi řemeslnými korporacemi dělbou práce př́mo v jedné dílně [Marx - Engels 1974: 32]. Zatímco Marxovi a Engelsovi předchůdci explicitně neříkají, že manufaktura je místem („dílnou“), jež pro svoji výrobní činnost potřebuje pokročilou dělbu práce, Marx s Engelsem to automaticky předpokládají.

Definitivní podobu dala manufaktuře příslušná část Kapitálu, ve které Marx shrnuje své předchozí postřehy. Manufaktura představuje nový způsob výroby, který v 16. století přispívá k rozšíření „kapitalistického“ hospodářství. Je místem s pokročilou dělbou práce, na kterém se procesy následující po sobě v čase přeměňují s pomocí jednoduchých strojů $\mathrm{v}$ procesy probíhající vedle sebe v prostoru. Manufaktura kombinuje práci dříve samostatných řemeslníků, kteří vykonávají dílčí operace pod jednou střechou nebo se vzájemně doplňují při výrobě téhož zboží. Manufaktura podrobuje najaté pracovníky hierarchickému vedení a disciplíně. Potlačuje v lidech jejich sklony a vlohy a pěstuje jednostrannou zručnost. Manufaktura činí tuto jednostrannost dědičnou a přenáší ji z generace na generaci [Marx 1953: 362-388]. 
Další významové rozdíly přinesl překlad Marxových spisů do ostatních jazyků, zejména do angličtiny. V anglickém vydání Kapitálu se manufaktura na několika místech překládá slovem manufactory ve smyslu dílny s pokročilou dělbou práce. Většinou se však v textu mluví o manufacture, a to i tam, kde se v němčině a češtině užívá výrazu Manufaktur, resp. manufaktura. Anglické manufacture je obecnější označení pro průmyslovou výrobu a výrobky. Podobně zachází se slovem manufactory Adam Ferguson, Adam Smith či Andrew Ure, ze kterých Marx vychází a na něž odkazuje. V jejich díle se slovo manufactory vyskytuje ojediněle. Mnohem zásadnější je naproti tomu manufacture, která zosobňuje výrobní princip dominantní v dané době [srov. Ferguson 1819: 200-201, 289, 340, 389; Smith 1843: 116, 136, 156, 187; Ure 1835: 205, 316].

Ztotožnění manufaktury s místem pokročilé dělby práce, resp. vývojovým stádiem továrny je nejspíše výsledkem kameralistické tradice. Justi jak známo tvrdí, že „pokud jde o manufaktury, dosáhli jsme všeho, čeho jsme si př́li; hlavním předmětem činnosti se proto musí stát fabriky“. Justi spojuje manufaktury s textilní, keramickou, sklářskou výrobou, zatímco „fabriky“ s hutní, železářskou a zbrojní výrobou [Justi 1758: nestránkovaná predmluva]. Podobně se vyjadřuje Sonnenfels, který uvádí, že puritáni umí dokonale zacházet se slovy: o manufaktuře mluví tam, kde se nepoužívá „kladivo“ ani „oheň“, například v manufakturách na sukno a bavlnu. Naproti tomu s železem a mosazí se pracuje ve „fabrikách“. Fabrika je podle Sonnenfelse obecnějším termínem, takže lze mluvit také o fabrice na sukno nebo bavlnu [Sonnenfels 1787: 12]. Podobně píše Marx v jedné poznámce, že zatímco továrna se v angličtině nazývá mill [mlýn], v německých technologických spisech z prvních desetiletí 19. století je název „Mühle“ [mlýn] synonymem nejen pro všechny stroje poháněné přírodními silami, nýbrž i pro všechny manufaktury, v nichž se užívá mechanických př́ístrojů [Marx 1978: 346-347].

Všechny tyto nuance, o kterých Marx píše, spoluutvářely definici historického pojmu manufaktura. Když čeští historici a historičky psali o různých aspektech raněnovověkých podniků, zmiňovali příslušné pasáže z Marxových (zprvu také Stalinových, později již pouze Leninových) spisů. At̉ už se jednalo o problém původní akumulace, kupeckého kapitálu, dálkového obchodu, oslabení cechovní organizace, ukázňování tuláků a bezzemků nebo místa s pokročilou dělbou práce, stačil odkaz na Marxe učinit z raně novověkého podniku manufakturu. Byt’ se v pramenech mohla vyskytovat pouze „fabrika“.

Bylo by možné se ptát, zda výše zmíněné problémy jsou dostatečným důvodem proto, aby byla raněnovověká manufaktura či fabrika prohlášená za kapitalistický podnik. V příslušné části Kapitálu se mimo jiné nachází podkapitolka nadepsaná Kapitalistický charakter manufaktury. Tato podkapitolka poskytuje podle mého názoru klíć, podle kterého je možné určit, zda manufaktury a fabriky měly co do činění s počátky kapitalismu. Jestliže v těchto manufakturách probíhala „přeměna společenských životních prostředků a výrobních prostředků v kapitál“, manufaktury si podrobovaly „individuální pracovní sílu“, pěstovaly u dělníků ,jednostrannou zručnost“, potlačovaly „svět produktivních sklonư“, zbavovaly dělníka samostatné činnosti „podle jeho přirozených vloh“, stavěly proti zaměstnancům jejich „znalosti, důvtip a vưli“ apod., měly podle Marxe kapitalistický charakter [Marx 1953: 386-388].

Kapitalistický charakter podniku zakládá moment, ve kterém „kapitalista“ zastupuje vůči jednotlivému pracovníkovi jednotu a vůli společenského pracovního tělesa (kolektivu). Jedná se o proces ochuzování pracovníka o individuální produktivní síly 
a obohacování pracovního kolektivu (tedy i kapitálu) o společenské produktivní síly. S odkazem na skotského osvícenského filozofa a Smithova učitele Adama Fergusona lze říci, že manufaktury prospívají nejlépe tam, kde je potlačen duchovní život („nevědomost je matkou průmyslu“). Na takovém místě se dílna stává strojem, jehož částmi jsou lidé. Politický ekonom a moralista Adam Smith prohlašuje, že „duševní schopnosti velké většiny lidí se vytvářejí v souvislosti s jejich obvyklým zaměstnáním“. Člověk, který stráví celý život prováděním několika jednoduchých operací a nemá příležitost rozvíjet své duševní schopnosti, pozbývá odvahu. Jednotvárná činnost oslabuje činnost těla a činí ho nezpůsobilým napínat po delší dobu síly př̀i nějakém jiném zaměstnání než při tom, $\mathrm{v}$ němž je vycvičen [Smith 1843: 327].

Podíváme-li se podrobně na jednotlivé historické studie, tak málokterá z nich pracuje s „kapitalistickým charakterem“ manufaktury. Většinou mechanicky označují podniky z 18. století za manufaktury, protože odpovídají zavedenému marxistickému určení manufakturního období. Dalším znakem manufaktury je převaha rukodělné výroby, která využívala zviŕecí a lidskou sílu. Naproti tomu místa, na nichž se objevuje mechanická hnací síla, parní pohon a důmyslnější strojní zařízení, se automaticky považují za kapitalistickou továrnu [Komlosy 1988: 157].

Na tento problém upozornil ostatně již Weber, podle kterého byla představa o manufaktuře jako objektu či budově založena na marxistické definici. Ta omezuje manufakturu na velkou dílnu, ve které se bez použití dokonalejších technických prostředků poprvé uplatnila svobodná práce a disciplinace dělníků. Weber poukazuje na to, že Marxova kazuistika vycházela z textilní výroby v Anglii. Přechod mezi manufakturou a továrnou (fabrikou) byl podle Webera mnohem plynulejší. Vzhledem $\mathrm{k}$ tomu, že se Marxova definice dala vztáhnout na mnohem více př́padů z minulosti i ze současnosti, bylo obtižné považovat manufakturu za svébytný, historický „stupeň“ výroby [Weber 1923: 149; Uhl 2015].

Jak je zřejmé $\mathrm{z}$ edic pramenů, zkoumání kapitalistického charakteru raně novověkých podniků nebylo často možné kvưli mezerovitému charakteru pramenů, ve kterých navíc prevevládalo označení fabrika [Otruba 1981]. Pro analýzu ekonomických, společenských a morálních poměrů $\mathrm{v}$ jednotlivých manufakturách a fabrikách jsou vhodné jiné typy pramenů. Zejména ty, které zohledňují životní dráhu jednotlivých pracovníků nebo v ideálním prŕípadě zprostředkují jejich subjektivní pohled. Jak jinak zjistit individuální podrobení, potlačení různorodých vloh nebo zbavování přirozených sklonů? Například Johann Richter reprodukuje vyšetřovací protokol zběhlých tkalcủ $\mathrm{z}$ hornolitvínovského podniku. Ti si údajně stěžovali, že s nikým „nemohli mluvit česky, dostali malý plat a špatnou postel [...] a obávali se, že nenatrefí na jemnèjší práci" [Richter 1933: 231]. Dokud nebudou zohledněny další takové prameny, bude používání pojmu manufaktura vyvolávat terminologický zmatek, analytické těžkosti a interpretační pochyby.

\section{Závěr}

V marxistickém pojetí tvořila manufaktura jednu etapu historického procesu („kapitalistické výroby“). Pokud tento proces omezíme na dějiny výrobních prostředků a výrobních sil (tzn. na otázku, jaké výrobní nástroje se používaly popř́ípadě, jakým způsobem byla výroba organizována $\mathrm{v}$ dané době), lze ho s pomocí tohoto pojmu celkem dobře periodizovat. Při vlastní analýze historické reality už tolik nápomocný být 
nemusí. O tom, jaký podnik byl nebo nebyl manufakturou, rozhodovali totiž sami historici, někdy velmi libovolně, pomocí narativní zkratky a navzdory pramenům, v nichž nebylo možné samotný termín doložit, resp. byly s ním spojeny další významy. V různých evropských jazycích, obdobích a výrobních odvětvích označovala manufaktura vždy trochu něco jiného. Hranice mezi označeními byla dlouho nejasná a propustná [Purš 1973: 32-52; Pollard 1981: 78]. V každodenní komunikaci byla manufaktura zaměnitelná s fabrikou [Hilger 1975: 232].

Obrat k jazyku, včetně pečlivého zacházení s prameny, které zaznamenala historiografie v posledních desetiletích, nabádá $\mathrm{k}$ vyšší citlivosti vůči dobovému pojmosloví. Přinejmenším sémanticky je výraz manufakturní dưm, dílna, pracovna nebo fabrika přesnější a korektnější označení, které respektuje historickou realitu. Jsem si vědom, že historici a historičky jsou ve svém zkoumání, vždy vedeni výchozí politickou, společenskou, kulturní situací apod. Historickou realitu nemohou nikdy v úplnosti poznat ani rekonstruovat. Nechci také tvrdit, že by měli svoje poznání omezit pouze na sémantické prostředky historických pramenů, které jsou ostatně jejich konstruktem, resp. zlomkem, stopou či pozůstatkem minulosti. V tomto ohledu se jedná vždy o redukci komplexity. Přesto bych rád upozornil, že pečlivé, kritické a reflektované zacházení s dobovou terminologií může přinést přesnější a přesvědčivější zjištění.

Každá učebnicová či historická definice, manufaktury nevyjímaje, je velmi obecná a široká. Musí zahrnovat množství empirických př́ikladů, které by měla smysluplně analyzovat. Měla by být ideálním typem v tom nejlepším slova smyslu, jak na to upozornil samotný Weber, který se problematice manufaktur věnoval v souvislosti s dějinami moderního kapitalismu. V tomto ohledu se zdá zajímavější analytický nástroj poskytovat dobový termín. To vůbec nevylučuje, že na konci zkoumání lze přistoupit k zobecnění nových poznatků a nové definici pojmu, jak doporučuje např́iklad berlínská historička Margit Pernau [Pernau 2018: 15, 25-27]. Kromě toho je žádoucí přihlédnout k výskytu toho kterého termínu v každodenních situacích - sociálních interakcích, v nichž lidé tyto termíny používají. Vzhledem $\mathrm{k}$ tomu, že většina historických pramenů je pozůstatkem sociální komunikace, stojí za to být pozornější k jejich sdělení. Potom snad budeme schopni této komunikaci (a historii vůbec) lépe porozumět.

\section{Poděkování}

Tento text je výsledkem standardního projektu č. 18-03921S, Sociální otázka in situ: sociální politika průmyslových podniků v českých zemích, 1879-1914, který podpořila Grantová agentura České republiky.

\section{Literatura}

Aubin, Gustav [1937]. Aus der Entstehungsgeschichte der nordböhmischen Textilindustrie. Deutsches Archiv für Landes- und Volksforschung 2 (1): 353-377.

Baumann, Bedřich a kol. [1951]. Učební texty pro dějepis: část II. Dějiny nové a nejnovějǔí doby. Státní nakladatelství v Praze.

Becher, Johann Joachim [1668], Politischer Discurs: von den eigentlichen Ursachen des Auf- und Abnehmens der Städte, Länder und Republicken in specie, wie ein Land Volkreich und Nahrfaht zu machen und in 
eine rechte Societatem civilem zu bringen. Frankfurt am Main: Johann David Zunners. Dostupné z: $<\mathrm{http}: / /$ www.deutschestextarchiv.de/book/view/becher_discurs_1668? $\mathrm{p}=5>$ [14. 10. 2018].

Becher, Johann Joachim [1673]. Politischer Discurs: von den eigentlichen Ursachen des Auf- und Abnehmens der Städte, Länder und Republicken in specie, wie ein Land Volkreich und Nahrfaht zu machen und in eine rechte Societatem civilem zu bringen. Frankfurt am Main: Johann David Zunners. Dostupné z: <https://reader.digitale-sammlungen.de/de/fs1/object/display/bsb11281892_00007.html> [14. 10. 2018].

Berend, Ivan T. [2006]. An Economic History of Twentieth-Century Europe: Economic Regimes from Laissez-Faire to Globalization. New York - Cambridge: Cambridge University Press.

Berg, Maxine [1994]. The Age of Manufactures, 1700-1820: Industry, Innovation and work in Britain. London - New York: Routledge.

Bićanić, Rudolf [1951]. Doba manufakture u Hrvatskoj i Slavoniji (1750-1860). Zagreb: Jugoslavenska akademija znanosti i umjetnosti.

Bücher, Karel [1897]. Vznik národního hospodářství: šest přednášek. Přeložil Josef Gruber. Praha: Jan Laichter.

Burian, Vladimír [1961]. První moravský merkantilista Pavel Hynek Morgentaller: život a dílo. In. Brno $v$ minulosti a dnes 3 (III): 72-92.

Cerman, Markus - Ogilvie Sheilagh C. [1994]. Proto-Industrialisierung in Europa: industrielle Produktion vor dem Fabrikszeitalter. Wien: Verlag für Gesellschaftskritik.

Cerman, Markus [2002]. Soziale Differenzierung, proto-industrielle Entwicklung und Gutherrschaft in Frýdland und Liberec, 16.-18. Jahrhundert. In. Markus Cerman - Hermann Zeithoffer, Soziale Strukturen in Böhmen: ein regionaler Vergleich von Wirtschaft und Gesellschaft in Gutsherrschaften, 16.-19. Jahrhundert. Wien: Verlag für Geschischte und Politik, München: Oldenbourg Wissenschaftsverlag, s. 174-190.

Deak, John [2015]. Forging multinational state: state making in Imperial Austria from the Enlightenment to the First World War. Stanford: Stanford University Press.

Designation Iconographica Oberlevtensdorfenses Pannarias Officinas Vvlgo Fabricas Penicilli arbitrio Representans [1728]. Prag: s. n. Jan Josef Valdštejn. Dostupné z: <https://books.google.cz/books?id $=\mathrm{IkNdAAAAcAAJ \& printsec}=$ frontcover\&hl $=\mathrm{cs} \&$ source $=$ gbs_ge_summary_r\&cad $=0 \# \mathrm{v}=$ onepage\&q\&f $=$ false $>$ [14. 10.2018].

Dobb, Maurice [1946]. Studies in the Development of Capitalism. London: George Routledge \& Sons.

Doležalová, Antonie [2018]. A History of Czech Economic Thought. London: Routledge.

von Ebengreuth, Arnold Luschin [1896]. Österreichische Reichsgeschichte (Geschichte der Staatsbildung, der Rechtsquellen und des öffentlichen Rechts). Ein Lehrbuch. Bamberg: C. C. Buchner Verlag.

d'Elvert, Christian [1870]. Zur Cultur-Geschichte Mährens und Oest. Schlesiens, 3. Theil. Brünn: Commission der Buchhandlung A. Ritsch. Dostupné z: <http://www.digitalniknihovna.cz/svkos/view /uuid:ec1ce2e0-1730-11e0-aa9e-0013d398622b?page=uuid:cf3alb10-1727-11e0-9b5c-0013d398622b> [12. 10. 2018].

Ferguson, Adam [1819]. An Essay on the History of Civil Society. Philadelphia. Dostupné z: <https://books .google.cz/books?id=04uAAAAYAAJ\&printsec $=$ frontcover\&dq=adam+ferguson\&redir_esc $=\mathrm{y} \# \mathrm{v}$ $=$ onepage \&q=intelectual \&f=false $>$ [24. 9. 2018].

Forberger, Rudolf [1958]. Die Manufaktur in Sachsen vom Ende des 16. bis zum Anfang des 19. Jahrhunderts. Berlin: Akademie Verlag.

Fournier, August [1887]. Handel und Verkehr in Ungarn und Polen um die Mitte des 18. Jahrhunderts. Ein Beitrag zur Geschichte der österreichischen Commerzialpolitik. In. Archiv für Österreichische Geschichte LXIX (1887): 319-465.

Freudenberger, Herman [1958]. The Manufacturing Period in Bohemia by Arnošt Klíma. The Journal of Economic History 3 (18): 363-364.

Freudenberger, Herman [1960]. The Woolen-Goods Industry of the Habsburg Monarchy in the Eighteenth Century. The Journal of Economic History 3 (20): 383-406.

Freudenberger, Herman [2003]. Lost Momentum: Austrian Economic Development, 1750s-1830s. Vienna: Böhlau.

Freudenberger, Herman - Redlich, Fritz [1964]. The Industrial Development of Europe. Reality, Symbols, Images. Kyklos 3 (17): 372-400. 
Good, David F. [1984]. The Economic Rise of the Habsburg Empire 1750-1914. Berkeley - Los Angeles London: University of California Press.

Górny, Maciej [2018]. Mezi Marxem a Palackým: historiografie v komunistickém Československu. Praha: Volvox Globator.

Guarient und Raall, Franz Anton von [1704]. Codicis Austriaci ordine alphabetico complilati pars prima. Wien: Leopold Voigt, Univers. Buchdruckern. Dostupné z: <https://digi.ub.uni-heidelberg.de/diglit /codexaustriacus1704bd1/0279/image> [27. 1.2019].

Hallwich, Herrmann [1869]. Die erste Fabrik in Reichenberg. Reichenberg: In Commission bei Franz Jannasch.

Hilger, Dietrich [1975]. Fabrik, Fabrikant. In. Koselleck, Reinhart - Meier, Christian Meier (ed.). Geschichtliche Grundbegriffe: historisches Lexikon zur politisch-sozialen Sprache in Deutschland. Stuttgart: Klett-Cotta, s. 229-252.

Himl, Pavel [2003]. Die „armben Leüte“ und die Macht: die Untertanen der südböhmischen Herrschaft Český Krumlov / Krumau im Spannungsfeld zwischen Gemeinde, Obrigkeit und Kirche (1680-1781). Stuttgart: Lucius \& Lucius.

Hobsbawm, Eric J. [1954]. The Crisis of the 17th Century - II. Past \& Present 6 (3): 44-65.

Hörnigk, Philipp Wilhelm von [1684]. Oesterreich uber alles wann es nur will: das ist wohmeinender Fürschlag, wie mittelst einer wolbestellten Lands-Oeconomie die Kayserl. Erbland in kurzem über alle andere Staat von Europa zu erheben und mehr als einiger derselben von denen andern independent $z$ u machen. Nürnberg: Durch einen Liebhaber der Kayserl. Erbland Wolfahrt. Dostupné z: <https:// books.google.cz/books?id=6LkAAAAAcAAJ\&printsec=frontcover\&source=gbs_ge_summary $\_\mathrm{r} \& \mathrm{cad}=0 \# \mathrm{v}=$ onepage\& $\& \mathrm{f}=$ false $>[14.10 .2018]$.

Horský, Jan [2015]. Teorie a narace: $k$ noetice historické vědy a teorii kulturního vývoje. Praha: Argo.

Hroch, Miroslav [1956]. Severoněmecká prístavní města a Albrecht $z$ Valdštejna: príspěvek k pokusưm o nový rozvoj hansovních měst v letech 1627-1630. Praha: FF UK (rkp. diplomové práce).

Hroch, Miroslav [1961]. Wallensteins Beziehungen zu den wendischen Hansestädten. Hansische Studien 1 (8): 135-161.

Husová, Marie [1946]. Manufaktura a továrna: příspěvek k historickému pojmosloví. Studie $k$ hospodářským a sociálním dějinám 1-2 (1): 63-72.

Ingrao, Charles W. [1994]. The Habsburg Monarchy: 1618-1815. New York: Cambridge University Press.

Ira, Jaroslav [2004]. Dějiny politických pojmů: nové roviny, nové př́stupy a nové otázky. Dějiny - teorie kritika 2 (1): 213-236.

Janák, Jan [1999]. Déjiny Moravy. Díl 3/1, Hospodářský rozmach Moravy, 1740-1918. Brno: Muzejní a vlastivědná společnost.

Jiroušek, Bohumil [2004]. Josef Macek. Mezi historií a politikou. Praha: Výzkumné centrum pro dějiny vědy.

Jiroušek, Bohumil a kol. [2008]. Proměny diskurzu české marxistické historiografie (Kapitoly z historiografie 20. století). České Budějovice: Jihočeská univerzita v Českých Budějovicích, Filozofická fakulta, Historický ústav.

Justi, Johann Heinrich Gottlob [1758]. Vollständige Abhandlung von denen Manufakturen und Fabriken. Kopenhagen: Auf Kosten Rothenschen Buchhandlung. Dostupné z: <https://books.google.cz /books?vid=NKP:1002596858\&printsec=frontcover\#v=onepage \&q\&f=false $>$ [12. 10. 2018].

Kábová, Hana [2008]. Mladý Jan Pachta. In. Jiroušek, Bohumil a kol. Proměny diskurzu české marxistické historiografie (Kapitoly z historiografie 20. století). České Budějovice: Jihočeská univerzita v Českých Budějovicích, Filozofická fakulta, Historický ústav.

Kan, Sergej Borisovič [1952]. Dvě povstání slezských tkalců 1793-1844. Praha: Rovnost.

Klíma, Arnošt [1955]. Manufakturní období v Čechách. Praha: Academia.

Klíma, Arnošt [1959]. English Merchant Capital in Bohemia in the Eighteenth Century. The Economic History Review 2 (12): 34-48.

Klíma, Arnošt [1965]. Mercantislism in the Habsburg Monarchy - with special reference to the Bohemian Lands. Historica: Historical Sciences in Czechosloslowakia 2 (11): 95-119.

Klíma, Arnošt [1974]. The Role of the Rural Domestic Industry in Bohemia in the 18th Century. Economic History Review 1 (27): 48-56. 
Klíma, Arnošt [1975]. The Beginning of the Machine Building Industry in the Czech Lands in the First Half of the XIXth Century. The Journal of European Economic History 1 (4): 49-78.

Klíma, Arnošt [1977]. Industrial Growth and Entrepreneurship in the Early Stages of Industrialization in the Czech Lands. The Journal of European Economic History 3 (6): 549-574.

Komlosy, Andrea [1988]. An den Rand Gedrängt: Wirtschafts- und Sozialgeschichte des Oberen Waldviertels. Wien: Verlag für Gesellschaftskritik.

Kula, Witold [1956]. Szkice o manufakturach w Polsce 18 wieku. Warszawa: Państwowe Wydawnictwo Naukowe.

Kulischer, Josef [1954]. Allgemeine Wirtschaftsgeschichte des Mittelalters und der Neuzeit. Berlin: Rütten \& Loening.

von Loscani, Otto Ludwig [1756]. Relation über alle in folgenden fünf Commercialkreisen, benanntlich Königgratzer, Saatzer beide Antheile, Bunzlauer, Leutmeritzer und Stadt Prag, erhobenen Manufacturs-Gattungen. In. Archiv für österreichische Geschichte 68-69 (1886-87): 466-481.

Magnusson, Lars [2002]. Mercantilism: The Shaping of an Economic Language. London - New York: Routledge.

Mainuš, František [1959]. Plátenictví na Moravě a ve Slezsku v XVII. a XVIII. století. Ostrava: Krajské nakladatelství.

Marx, Karel - Engels, Bedřich [1974]. Manifest komunistické strany. Praha: Svoboda.

Marx, Karel [1950]. Bída filosofie. Praha: Svoboda.

Marx, Karel [1953]. Kapitál: kritika politické ekonomie - díl první. Praha: Státní nakladatelství politické literatury.

Masarykův slovník naučný, díl IV [1929]. Praha: nákladem „Československého kompasu“.

Maur, Eduard [1974]. Populační teorie a populační politika v českých zemích za feudalismu. Demografie 2 (16): 133-146.

Mendl, Bedřich [1931]. Hospodářský vývoj Evropy. Praha: Státní nakladatelství.

Mendl, Bedřich [1939]. Koloniální zápasy a nové směry hospodářské. In. Šusta, Josef a kol. Dějiny lidstva od pravěku k dnešku: bronzová skála moci státní 1650-1789. Praha: Melantrich.

Mokyr, Joel [2003]. The Oxford Encyclopedia of Economic History, 2. Oxford: Oxford University Press.

Morávková, Naděžda [2013]. František Graus a československá poválečná historiografie. Praha: Academia.

Morgenthaler, Paul Ignaz [1649]. Generales Florentis et Intereuntis Reipublicae Causae. Viennae Austriae: Typis Matthaei Rictij.

Myška, Milan [1979]. Pre-Industrial Iron-Making in the Czech Lands: the Labour Force and Production Relations, 1350-1840. Past \& Present 1 (82): 44-72.

Myška, Milan [2010]. Z díla hospodářského historika. Ostrava: Ostravská univerzita v Ostravě.

Myška, Milan [2013]. Vzpomínky prof. Arnošta Klímy na Mezinárodní kongres historiků ve Stockholmu $\mathrm{v}$ roce 1960. Historica - revue pro historii a př́buzné védy 1 (4): 87-95.

Nešpor, Zdeněk R. [1999]. Pojmy „církev“ a „sekta“v českém předmarxistickém dějepisectví. In. Horský, Jan. Kulturní a sociální skutečnost v dějezpytném myšlení. Ústí nad Labem: Albis International.

Nodl, Martin [2007]. Dějepisectví mezi védou a politikou: úvahy o historiografii 19. a 20. století. Brno: CDK. Nodl, Martin [2007]. Die hussitische Revolution. Zur Genese eines Forschungsparadigmas in der Tschechischen Historiografie der 1950er und 1960er Jahre. Bohemia: Zeitschrift für Geschichte und Kultur der böhmischen Länder 1 (47): 151-171.

Novotný, Karel [1956]. Klášterní manufaktura v Oseku v 18. století. Praha: FF UK (rkp. diplomové práce). Novotný, Karel [1967]. Klášterní manufaktura v Oseku v 18. století. AUC Philosophica et historica (3): 8-83. Novotný, Karel [1993]. Severočeští tiskaři kartounu v první polovině 19. století. Díl 1. Praha: Karolinum.

Otruba, Gustav hrsg. unter Mitarbeiten von Lang, Manfred, Steindl, Harald [1981]. Österreichische Fabriksprivilegien vom 16. bis 18. Jahrhundert und ausgewählte verwandte Quellen zur Frühgeschichte der Industrialisierung. Wien: Böhlau.

Ottưv slovník naučný, šestnáctý díl [1900]. Praha: vydavatel a nakladatel J. Otto v Praze.

Paulinyi, Ákoš [2002]. Průmyslová revoluce: o pưvodu moderní techniky. Praha: ISV.

Pekař, Josef [1914]. Dějiny naši říše se zvláštním zřetelem ke královstvím a zemím v říšské radě zastoupeným. Praha: Nákladem Historického klubu v Praze.

Pekař, Josef [1921]. Dějiny československé. Praha: Nákladem Historického klubu v Praze. 
Pernau, Margit [2018]. Einführung: Neue Wege der Begriffsgeschichte. Geschichte und Gesellschaft 1 (44): $5-28$.

Pollard, Sidney [1981]. Peaceful Conquest: the industrialization of Europe, 1760-1970. Oxford: Oxford University Press.

Pražáková-Seligová, Markéta [2015]. Život poddaných v 18. století: osud, nebo volba? K demografickým, hospodářským, sociálním a rodinným aspektům života venkovských poddaných na panství Horní Police. Praha: Toga.

Pribram, Alfred Francis [1898]. Das böhmische Commerzkollegium und seine Tätigkeit. Prag: Verlag für Geschichte der Deutschen in Böhmen.

Přibram, Karl [1907]. Geschichte der österreichischen Gewerbepolitik von 1740 bis 1860. Erster Band, Leipzig: Verlag von Duncker \& Humblot.

Purš, Jaroslav [1973]. Průmyslová revoluce: vývoj pojmu a koncepce. Praha: Academia.

Rákosník, Jakub [2008]. Tř́́dní boj v marxistické historiografii. In. Jiroušek, Bohumil. Proměny diskurzu české marxistické historiografie (Kapitoly z historiografie 20. století). České Budějovice: Jihočeská univerzita v Českých Budějovicích, Filozofická fakulta, Historický ústav.

Richter, Johann [1933]. Materialien zur Geschichte der Duxer Manufaktur. Mittheilungen des Vereines für Geschichte der Deutschen in Böhmen 3-4 (71): 228-251.

Řezníková, Lenka [2018]. Ad majorem evidentiam: literární reprezentace „zrejmého“v textech J. A. Komenského. Praha: Filosofia.

Seidlerová, Irena [2004]. Válečná zkušenost Františka Grause. In. Beneš, Zdeněk - Jiroušek, Bohumil Kostlán, Antonín. František Graus - člověk a historik. Praha: Výzkumné centrum pro dějiny vědy.

Schindler, Emanuel [1904]. Merkantilismus a státní praxe v Rakousku za Leopolda I. Praha: Česká grafická společnost „Unie“.

Schröder, Wilhelm von [1752]. Fürstliche Schatz- und Rentkammer, nebst seinem Tractat vom Goldmachen, wie auch vom Ministrissimo oder Oberstaatbedienten. Königsberg - Leipzig: Verlegts Johann Heinrich Hartung. Dostupné z: <https://books.google.cz/books?id=XVQKPl6KOToC\&printsec=frontcover\&source $=$ gbs_ge_summary_r\&cad $=0 \# \mathrm{v}=$ onepage $\& \mathrm{q} \& \mathrm{f}=$ false $>[12.10 .2018]$.

Smith, Adam [1843]. An Inquiry Into the Nature and Causes of the Wealth of Nations. Edinburgh: Thomas Nelson. Dostupné z: <https://books.google.cz/books?id=8k_K8rf2fnUC\&printsec=frontcover \&source=gbs_ge_summary_r\&cad $=0 \# \mathrm{v}=$ onepage $\& \mathrm{q}=$ manufactory $\& \mathrm{f}=$ false $>[12.10 .2018]$.

Smutný, Bohumír [2002]. Potštejnská manufaktura na česko-kladském pomezí. Studie o východočeském plátenictví v letech 1754-1761. Hradec Králové: Kladský sborník. Supplementum 4.

Slovník naučný, díl pátý [1866]. Praha: nákladem knihkupectví I. L. Kobra.

Sombart, Werner [1902]. Der moderne Kapitalismus. Leipzig: Duncker \& Humblot.

Sonnenfels, Joseph [1787]. Grundsätze der Polizey, Handlung und Finanz. Wien: Kurzbek. Dostupné z: $<$ https://reader.digitale-sammlungen.de/de/fs1/object/display/bsb11347416_00005.html> [12. 10. 2018].

Stern, Philip J. - Wennerlind, Carl [2014]. Mercantilism Reimagined: Political Economy in Early Modern Britain and Its Empire. Oxford: Oxford University Press.

Sterzinger, Josef V. [1931]. Encyklopedický německo-český slovník. III. díl. Praha: nakladatelství J. Otto.

Supple, Barry [1977]. The Nature of Enterprise [1977]. In. The Cambridge Economic History of Europe, Volume V. Cambridge: Cambridge University Press.

Šebánek, Jindřich [1931]. Textilní podniky moravských Kouniců. Z dějin industrialisace na Moravě na počátku 18. století. Časopis Matice Moravské 55: 95-168, 418-468.

Šebánek, Jindřich [1932]. Textilní podniky moravských Kouniců. Z dějin industrialisace na Moravě na počátku 18. století. Časopis Matice Moravské 56: 101-180.

Špiesz, Anton [1961]. Manufaktúrne obdobie na Slovensku, 1725-1825. Bratislava: Vydavatel'stvo Slovenskej akadémie vied.

Štefanová, Dana [2009]. Erbschaftspraxis, Besitzertransfer und Handlungsspielräume von Untertanen in der Gutsherrschaft: Die Herrschaft Frýdlant in Nordböhmen, 1558-1750. Wien: Verlag für Geschichte und Politik. München: Oldenbourg Wissenschaftsverlag.

Šubrtová, Alena [2006]. Dějiny populačního myšlení v českých zemích. Praha: Česká demografická společnost. 
Teich, Mikuláš [2015]. The Scientific Revolution Revisited. Cambridge: Open Book Publishers.

Uhl, Karsten [2015]. Räume der Arbeit: Von der frühneuzeitlichen Werkstatt zur modernen Fabrik. In. Europäische Geschichte Online (EGO), 11.3. 2015. Dostupné z: <http://ieg-ego.eu/?set_language=de> [13. 10. 2018].

Ure, Andrew [1835]. The Philosophy of Manufactures: or An Exposition of the Scientific, Moral and Commercial Economy of the Factory System of Great Britain. London: Charles Knight. Dostupné z: <https:// archive.org/details/philosophymanuf01uregoog/page/n5 [13. 10. 2018].

Válka, Josef [1956]. K otázce pưvodní akumulace kapitálu v Čechách a na Moravě v 16. stol. Sborník prací Filozofické fakulty brněnské univerzity: řada historická (C) 3 (5): 103-122.

Válka, Josef [1996]. Déjiny Moravy - Díl 2: Morava reformace, renesance a baroka. Brno: Muzejní a vlastivědná společnost.

Velková, Alice [2009]. Krutá vrchnost, ubozí poddaní? Proměny venkovské rodiny a společnosti v 18. a v první polovině 19. stoletín na príkladu západočeského panství Štáhlavy. Praha: Historický ústav.

Wakefield, Andre [2009]. The Disordered Police State: German Cameralism as Science and Practice. Chicago: University of Chicago Press.

Weber, Max [1923]. Wirtschaftsgeschichte - Abriss der universalen Sozial- und Wirtschaftsgeschichte. München - Leipzig: Verlag von Duncker \& Humblot.

Zdeněk Nebřenský se zabývá sociálními a kulturními dějinami střední Evropy v 19. a 20. století, zejména dějinami polské a československé inteligence v padesátých a šedesátých letech 20. století a dějinami textilních továren v habsburské monarchii ve druhé polovině 19. století. 